\title{
Études/Inuit/Studies
}

\section{Introduction: Current research in Chukotka by local researchers}

\section{Virginie Vaté}

Volume 31, numéro 1-2, 2007

Tchoukotka

Chukotka

URI : https://id.erudit.org/iderudit/019729ar

DOI : https://doi.org/10.7202/019729ar

Aller au sommaire du numéro

\section{Éditeur(s)}

Association Inuksiutiit Katimajiit Inc.

Centre interuniversitaire d'études et de recherches autochtones (CIÉRA)

\section{ISSN}

0701-1008 (imprimé)

1708-5268 (numérique)

Découvrir la revue

\section{Citer cet article}

Vaté, V. (2007). Introduction: Current research in Chukotka by local researchers. Études/Inuit/Studies, 31(1-2), 303-304.

https://doi.org/10.7202/019729ar d'utilisation que vous pouvez consulter en ligne.

https://apropos.erudit.org/fr/usagers/politique-dutilisation/ 


\section{Introduction: Current research in Chukotka by local researchers}

\section{Guest-edited by \\ Virginie Vaté*}

A special issue devoted to recent research in Chukotka would not be complete if it included only external points of view and ignored the contributions of local researchers. Chukotka specialists are aware of the work being done by local researchers and are in dialogue with them. Unfortunately, however, our colleagues in Chukotka have restricted access to the global academic world. In most cases, literature published abroad is either unavailable in Chukotka or available only in languages that limit its local accessibility. The language barrier also makes it difficult for local researchers to publish their work in international journals, though differences in methodology and limited publication opportunities also play a role. As a result, most of the publications by local researchers are not widely available; they are printed in limited editions and their distribution is uneven.

Concerned with this problem, Yvon Csonka, guest editor of this special issue of Études/Inuit/Studies, has made an effort to open channels between local researchers and the larger scientific community in two ways: first, by integrating several contributions of researchers originating from Chukotka (see for instance the texts by Zoia WeinsteinTagrina or Larissa Abryutina) and second, by inviting me to edit a collection of papers written by colleagues in Chukotka who are conducting social scientific research on various issues in the region. To this end, I contacted several persons and institutions and got feedback from the five authors represented in this dossier. Their texts can be read individually, but taken together, they serve to illustrate the wide range of issues that concern local researchers, including Chukchi language, clothing, ethnicity, traditional land use, and human-animal relations. Due to spatial limitations, their presentations had to be kept short: I asked the authors to concentrate on the aims, the methodological aspects, and the results of their research. But their texts should also be seen as an invitation to interested readers to get in touch with these researchers directly.

The authors of the following texts are affiliated with different institutions based in Anadyr, the regional capital. These include the Chukotka Unit of the North-Eastern Institute for Science and Research (Far-Eastern Division of the Russian Academy of Science), the Chukotka Association of Traditional Marine Mammal Hunters (known as ChAZTO), and the Museum Center Heritage of Chukotka.

C.N.R.S., Groupe «Sociétés, Religions, Laïcités», UMR 8582 EPHE-CNRS, 59-61 rue Pouchet, 75849

Paris Cedex 17, France. virginie.vate@gsrl.cnrs.fr 
The Chukotka Unit of the North-Eastern Institute for Science and Research, locally known as the NITs (Nauchnyi Issledovatel'skii Tsentr, Centre for Scientific Research), is represented here by three contributions. Headed by Oleg Tregubov, the NITs is one of the oldest institutions in Chukotka and within the Far-Eastern Division of the Russian Academy of Science'. Growing out of the Anadyr permafrost station Glavsevmorputi, founded in 1935, it has been devoted, mainly, to research on and methods of sustainable engineering and construction on permafrost, and to geological surveys carried out for the exploitation of natural resources in the region. Today, staff members of the Chukotka Unit conduct research and monitor developments in three main areas: 1) Chukotka permafrost landscapes in the context of environmental and technological changes (four researchers); 2) natural water in Chukotka - hydrogeology, hydrology, and hydrochemistry (two researchers); and 3) indigenous traditional economy and linguistic processes in Chukotka (five researchers: G.I. Ranavrol'tyn, V.V. Golbtseva, N.I. Vukvukai, V.M. Etylin, and V.N. Nuvano). Researchers from outside of Chukotka, including Michael Dunn, Tokusu Kurebito, and Charles Weinstein in the field of linguistics and Patty Gray, Igor Krupnik, Kazunobu Ikeya, and myself in the field of anthropology, have benefited from discussions and exchange with the researchers of this institution.

To some people, local research production may seem to be largely absent or rather modest in scale. Given the low population and the general conditions in the region, however, the achievements of local researchers, in my view, should be taken into consideration and encouraged. As members of the international research community, we have an obligation to help promote local research. Even if several national funding agencies, particularly in North America, are now supportive of local indigenous research, I believe that it is not always easy to develop collaborative research and I would argue for the necessity of more incentives in this direction, notably in Europe ${ }^{2}$. I hope that the publication of this collection of short research notes will contribute, in some small way, to encouraging collaboration with researchers in local institutions - a development which would be beneficial to all participants in such collaborative endeavours.

1 All the information about the Chukotka Unit of the North-Eastern Institute for Science and Research was provided by N.I. Vukvukai, Scientific Secretary and Senior Research Fellow of the Unit. could write a paper together on the issue of the House of Culture in Chukotka. 